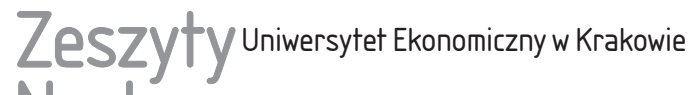 Naukowe
}

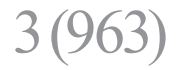

ISSN 1898-6447

Zesz. Nauk. UEK, 2017; 3(963): 87-102 DOI: 10.15678/ZNUEK.2017.0963.0306

Katarzyna Warmińska

Anna Urbaniak

\section{Czym jest Kraków? Analiza pola semantycznego*}

\section{Streszczenie}

W artykule przedstawiono sposoby definiowania Krakowa przez jego mieszkańców. Został on oparty na wynikach badań jakościowych, które opracowano z zastosowaniem analizy pola semantycznego. Dzięki temu możliwe stało się odtworzenie tego, w jaki sposób mieszkańcy określają Kraków, z czym się im kojarzy, czemu jest przeciwstawiany, jakie działania można podjąć wobec Krakowa i jakie działania podejmuje Kraków. Wnioski wynikające z analizy wskazują, że Kraków rozumiany jest w kategoriach miasta/miejsca.

Słowa kluczowe: analiza semantyczna, miasto, miejsce, socjologia miasta, Kraków, socjologia jakościowa.

\section{Wprowadzenie}

Celem artykułu jest ukazanie, w jaki sposób mieszkańcy rozumieją i definiują Kraków. Już na wstępie należy zaznaczyć, że w ramach przyjętej orientacji badaw-

Katarzyna Warmińska, Uniwersytet Ekonomiczny w Krakowie, Wydział Gospodarki i Administracji Publicznej, Katedra Socjologii, ul. Rakowicka 27, 31-510 Kraków, e-mail: warminsk@uek. krakow.pl

Anna Urbaniak, Uniwersytet Ekonomiczny w Krakowie, Wydział Gospodarki i Administracji Publicznej, Katedra Socjologii, ul. Rakowicka 27, 31-510 Kraków, e-mail: anna.urbaniak@uek. krakow.pl

* Artykuł powstał w ramach badań statutowych Katedry Socjologii finansowanych ze środków własnych przez Uniwersytet Ekonomiczny w Krakowie. 
czej nie pytano uczestników badań o Kraków jako miasto, a proszono jedynie o udzielenie odpowiedzi na pytanie: „czym jest Kraków?”. To oni sami określali, co rozumieją pod tym pojęciem. Najciekawsze z punktu widzenia autorek było bowiem odtworzenie perspektywy samych badanych. Dzięki zastosowaniu otwartej formuły można przyjąć, że odpowiedzi udzielane spontanicznie przez rozmówców dają badaczowi wgląd w struktury poznawcze wykorzystywane przez nich na co dzień. Wykorzystując podejście jakościowe, dzięki zastosowaniu analizy semantycznej starano się odtworzyć sposób rozumienia pojęcia Krakowa przez zidentyfikowanie, z jakimi pojęciami jest ono utożsamiane, z jakimi się kojarzy, jakim jest przeciwstawiane, jak jest opisywane, jakie działania może podejmować Kraków i jakie działania można podejmować wobec niego. Dzięki rekonstrukcji tych sieci znaczeń możliwe jest lepsze zrozumienie, czym jest Kraków w świadomości mieszkańców.

\section{Założenia metodologiczne}

W badaniach przyjęto perspektywę konstruktywistyczną. Oznacza to, że zadanie badacza polega na poznaniu i zrozumieniu, w jaki sposób rzeczywistość jest tworzona przez jednostki w procesie nadawania znaczeń. Sensy tworzone przez jednostki nie są w prosty sposób determinowane przez ludzki umysł, lecz są pochodną dynamicznych procesów, takich jak myślenie, kreacja i interpretacja, które przebiegają w określonym czasie i miejscu. Z tego wynika ich kontekstualny, historyczny i temporalny charakter (por. [Straś-Romanowska 2010, s. 101]).

Uznanie temporalnego i kontekstualnego charakteru doświadczeń jednostek jest jednym z głównych powodów, dla których w realizowanych badaniach zdecydowano się na prowadzenie analizy jednostkowych doświadczeń mieszkańców, osadzonych w kontekście Krakowa. Z tego względu w przedstawianym procesie badawczym zastosowano metodologię opierającą się na niektórych założeniach teorii ugruntowanej [Glaser i Strauss 1967, Konecki 2000, Charmaz 2013].

Należy podkreślić, że prezentowane analizy mają charakter eksploracyjny i są pilotażową częścią większego projektu badawczego, z tego względu ich zakres jest ograniczony.

W badaniach zastosowano teoretyczny dobór próby (por. [Glaser i Strauss 1967]). Oznacza to, że decyzja o doborze informatorów podejmowana była stopniowo, w sposób celowy, w trakcie analizowania zgromadzonego materiału. Przed rozpoczęciem procesu badawczego przyjęto jedynie dwa kryteria ograniczające wybór. Wynikały one ze sformułowanego problemu badawczego. Pierwsze kryterium dotyczyło faktu zamieszkiwania w Krakowie, drugie odnosiło się do wieku badanych (założono, że badaniami na tym etapie objęte zostaną jedynie osoby w wieku mobilnym). 
Ostatecznie w próbie znalazło się 52 respondentów, w tym 29 kobiet i 23 mężczyzn, w wieku 18-39 lat ${ }^{1}$. Spośród respondentów 15 mieszkało w Krakowie od urodzenia, a 37 urodziło się gdzie indziej i przeprowadziło się do Krakowa. Tak wyraźny udział ludności napływowej w próbie wynikał w głównej mierze z celowego doboru do próby przypadków skrajnych i podobnych.

Na potrzeby niniejszego opracowania w zgromadzonych wywiadach zakodowano ${ }^{2}$ wszystkie fragmenty wypowiedzi dotyczące słowa „Kraków”, po to aby móc przeprowadzić analizę semantyczną. Metoda pola semantycznego w wersji opracowanej przez R. Robin i jej zespół pracujący w Ośrodku Leksykologii Politycznej w Saint-Cloud jest dość restrykcyjną i ograniczona metodą [Robin 1980]. Natomiast zgodnie z rozumieniem przyjętym przez zespół kierowany przez B. Fatygę jest to otwarta propozycja metodologiczna, którą można rozwijać w zależności od potrzeb [Praktyki badawcze... 2015]. To drugie rozumienie jest zdecydowanie bliższe autorkom niniejszego opracowania.

\section{Wyniki}

\subsection{Uwagi ogólne}

Pierwszy etap analizy, zgodnie z zasadami analizy semantycznej, polegał na odnalezieniu czytelności znaczącej. W tym celu na podstawie analizowanych wywiadów dla słowa kluczowego „Kraków” utworzono sześć odrębnych sieci³ Pole semantyczne danego pojęcia (w tym wypadku „Kraków”) tworzone jest w wyniku uporządkowania wyodrębnionych sieci i umożliwia odkodowanie czytelności znaczącej (por. [Dudkiewicz 2006, s. 37]). W odróżnieniu od znanych badań M. Kłosińskiego [1994] celem przeprowadzonej analizy semantycznej było nie tyle sformułowanie definicji pojęcia kluczowego („Kraków”), które jest podmiotem pola, ale raczej odtworzenie sposobu myślenia o pojęciu. W tym celu wyodrębniono sieci:

1) ekwiwalentów (synonimów; z czym jest utożsamiany podmiot?),

2) określeń (jaki jest podmiot? jakie są jego cechy? itp.),

${ }^{1} \mathrm{~W}$ odniesieniu do cytowania wypowiedzi w artykule przyjęto następujący schemat: numer wywiadu/płeć (K - kobieta, M - mężczyzna)_wiek_(P - przybysz, U - urodzona/urodzony w Krakowie). Na potrzeby artykułu wykorzystano 59 wywiadów z ponad 70 zrealizowanych w ramach projektu, dlatego numeracja wywiadów wykracza poza nr 59.

2 Wykorzystując m.in. kody invivo.

${ }^{3}$ Wszystkie analizy przeprowadzono, wykorzystując specjalistyczne oprogramowanie do analizy jakościowej - RQDA. 
3) asocjacji (z czym kojarzony jest podmiot? z czym się wiąże? co mu towarzyszy?),

4) określeń (jaki jest podmiot? jakie są jego cechy? itp.),

5) opozycji (czemu przeciwstawiany jest podmiot? co jest jego przeciwieństwem?),

6) opisu działań podmiotu (co robi? jakie skutki wywołuje?),

7) opisu działań wobec podmiotu (jakie działania można wobec niego podąć?).

\subsection{Ekwiwalenty}

Ustalenie ekwiwalentu określenia „Kraków” jest kluczowe dla zrozumienia pozostałych aspektów, które rozpoznano w czasie badań. Elementy pola semantycznego ściśle wiążą się z tym, co dla rozmówców jest odpowiednikiem wspomnianego pojęcia.

\section{Kraków to miasto}

Jak pokazuje analiza zebranego materiału, dla zdecydowanej większości badanych ekwiwalentem Krakowa jest miasto. A. Majer w swoim opracowaniu pt. Miasta teoretyczne, będącym swoistym przeglądem różnych sposobów rozumienia miasta, zwraca uwagę, że obecnie istnieje wiele perspektyw teoretycznych, które wyjaśniają zjawiska uważane za miejskie. Pisze wprost o obfitości quasi-teorii lub pseudoteorii, koncepcji, metafor, porównań, epitetów, apokryfów, oksymoronów, hiperboli, stereotypów, klisz itp., o trudności jednoznacznego wskazania desygnatu pojęcia miasta [Majer 2015, s. 12]. W celach porządkowych wskazuje główne konteksty, w odniesieniu do których można analizować miasto. Są to m.in.: wielkość i status miasta, funkcje miasta, historyczno-funkcjonalna geneza miast, struktura urbanistyczna, orientacja polityczna władz lokalnych, uniwersalność czy unikatowość. Pisze też o innych ujęciach, których autorzy według przyjętych przez siebie kryteriów dokonują podziałów miast (np. za M. Castellsem dzieli miasta m.in. na kulturalne, racjonalne, organiczne). Zwraca też uwagę, że żadna $\mathrm{z}$ aktualnych orientacji teoretyczno-metodologicznych nie wyjaśnia miejskich problemów w sposób wyczerpujący. Wynika to z poszerzania się zainteresowań współczesnej socjologii i stałej krystalizacji jej aparatu pojęciowego. Miasto, zdaniem A. Majera, można rozpatrywać w aspekcie instytucjonalnym, organizacyjnym, przestrzennym, ekonomicznym, ekologicznym, prawnym, kulturowym, społecznym i wielu innych.

Poszukując wzorca miasta, A. Majer wskazuje socjologiczne formuły modelowania miasta „W ogóle”. Wskazane przez niego aspekty mogą być dobrym przewodnikiem przez meandry konceptualizacji miasta. Wskazuje on na następujące znaczenia: miasto jako struktura przestrzenna i wspólnota, w której obrębie 
zachodzą procesy gospodarowania, rozwija się kultura przekazywana międzypokoleniowo; miasto jako środowisko zamieszkania z charakterystycznym dla niego układem i wielkością w aspekcie demograficznym, zagęszczeniem populacyjnym, zróżnicowaniem zabudowy i właściwymi mu warunkami życia; miasto jako różnorodność estetyczna i społeczna, obszar nasycony symbolami, heterogeniczny w kontekście podmiotów i obiektów; miasto ujmowane z punktu widzenia mitów i stereotypów, poszukujące swej podmiotowości [Majer 2015, s. 110].

Analizując odpowiedzi na pytanie, czym jest Kraków, można wskazać trzy główne wątki: ujmowanie Krakowa jako miasta, jako miasta nacechowanego i jako miasta osobistego.

Część badanych odpowiadała krótko, że Kraków jest miastem: „No jest miastem” (22/K_22_U); „No nie wiem. Miastem po prostu” (27/K_26_U). Niekiedy, choć nieczęsto, pojawiały się wskazania dotyczące jego położenia geograficznego: „Yyy... jest to miasto na południu Polski” (31/K_28_P). Nie ma potrzeby przytaczać w tym miejscu innych wypowiedzi, gdyż były one zwykle jednowyrazowe czy jednozdaniowe.

Nie była to jednak dominująca formuła odpowiedzi. Najczęściej bowiem, jeśli stawiano znak równości między Krakowem a miastem, podmiot miasto/Kraków w tym samym zdaniu otrzymywał pewne charakterystyki, podlegał nacechowaniu - wraz z rzeczownikiem występowały przymiotniki. Można powiedzieć, że częściej Kraków jawił się w oczach uczestników badań jako miasto ,jakieś”, niż miasto po prostu. Określenia wpisywane były wprost w jego definicję. Należy zaznaczyć, że te złożone opisy pojawiały się niekiedy jako odpowiedź na pytanie zadane w pierwszej turze, ale również w kolejnych. Można wskazać kilka obszarów, w odniesieniu do których Kraków podlegał nacechowaniu. Najczęściej Kraków opisywany był jako miasto o pewnych walorach estetycznych, jako piękne lub najpiękniejsze: „Pięknym miastem” (12/K_21_P); „No Kraków moim zdaniem jest jednym z najpiękniejszych miast w Europie" (49/M_22_U). Uwidaczniało się wyraźne pozytywne ujmowanie tych cech.

Nawiązywano także do przeszłości, co znajdowało swoje odzwierciedlenie w określaniu Krakowa jako miasta zabytkowego, starego, historycznego. Kraków rozumiany był kilkakrotnie jako dawna stolica Polski: „Kraków jest dawną stolicą Polski i miejscem ważnym dla Polaków" (9/K_21_P). Ta sama respondentka stwierdziła także: „No Kraków jest na pewno dużym miastem” (9/K_21_P).

Oprócz wspomnianych nacechowań Krakowa w wypowiedziach pojawiały się też określenia wskazujące na to, dla kogo/czyje jest to miasto. Najczęściej mówiono, że jest to miasto turystów i studentów: „No przecież już mówiłam... miastem turystycznym” (23/K_23_P); „No... jest na pewno też miastem studentów... Czym jeszcze może być? Hmm... Jest jeszcze miastem pełnym tury- 
stów" (66/M_34_P). Kraków jako miasto posiada często więcej niż jeden atrybut - jest piękny, stary, duży, zabytkowy, ogromny i piękny.

Kwestia określeń i skojarzeń związanych z Krakowem powróci w dalszej części artykułu, gdyż były one poddane osobnej analizie.

Uwagę autorek zwrócił fakt, że dla sporej części badanych, parafrazując słowa jednego z rozmówców, Kraków nie jest po prostu miastem. Przywołany z nazwy jawi się od razu jako byt o pewnych właściwościach, o które nie trzeba dodatkowo pytać, gdyż same z siebie w jego definicji się mieszczą. Co więcej, można dostrzec waloryzację pozytywną Krakowa/miasta. Oprócz wskazanego pola estetycznego, historycznego i geograficznego pojawiło się też w kilku wypowiedziach pole afektywne, np. Kraków był cudowny, wspaniały: „Kraków dla mnie jest najcudowniejszym miastem" (17/K_22_P).

Opisując ekwiwalenty Krakowa, należy zwrócić uwagę na jeszcze jedną kwestię. Część rozmówców, odpowiadając na pytanie, czym jest Kraków, wyraźnie sytuowała swoją wypowiedź w kontekście „ja”. Chodzi o te stwierdzenia, w których pojawiały się wyraźne osobiste odniesienia. Przykładowo mówiono: „Jest moim miastem rodzinnym” (60/M_27_U); ,Jest to miasto najbliższe memu sercu... Kraków jest dla mnie miastem, gdzie czuję się najlepiej i gdzie jest super towarzystwo moje” (19/K_22_U); „Moim miastem, w którym się urodziłam i w którym funkcjonuję do dziś" (28/K_26_U). Warto podkreślić, że takie deklaracje składały przede wszystkim osoby urodzone w tym mieście, dla których Kraków posiada wyraźny wymiar osobisty.

\section{Kraków to miejsce}

Wśród uczestników badań były też takie osoby, które wskazywały na miejsce jako desygnat Krakowa. Gdy mówimy o czymś jako o miejscu, zwykle odnosimy się do przestrzennego aspektu świata/życia. W opracowaniu pt. Space and Place J.A. Agnew dokonuje szerokiego przeglądu ujęć pojęcia miejsca nie tylko w naukach geograficznych, ale też w filozofii czy naukach społecznych. Zwraca uwagę, że w najprostszym znaczeniu miejsce odnosi się do lokalizacji, umiejscowienia lub też zamieszkiwania gdzieś. Miejsce zdaje się być specyficzne, ulokowane, a przestrzeń ogólna [Agnew 2011].

Kategorii miejsca używa się na wiele sposobów, choć J.A. Agnew uważa, że można wyróżnić trzy zasadnicze aspekty, które pojawiają się, gdy poddana zostaje teoretycznej refleksji. Po pierwsze, miejsce to ulokowanie czy położenie w przestrzeni. Mieszczą się w jego obrębie aktywności i obiekty. Nie jest ono czymś izolowanym, ale połączonym z innymi na mocy wzajemnych oddziaływań, przepływów, dyfuzji. Przykładowo miasto jest traktowane jako system miejsc, w który to układ wpisana jest mobilność. Po drugie, miejsce ujmowane jest jako seria lokalizacji czy układ, w którego obrębie odbywają się codzienne 
aktywności. Wtedy staje się nie tylko pewnym adresem, ale „gdzie” społecznego życia. Za przykład mogą posłużyć takie społeczne układy życia codziennego, jak miejsca pracy, domy, galerie handlowe, które strukturalizując interakcje, pomagają tworzyć i utrzymywać wartości, postawy i działania. Po trzecie, miejsce ujmowane jest w kontekście poczucia miejsca czy identyfikacji z nim, poczucia przynależności do unikalnej wspólnoty, porządku wartości czy krajobrazu [Agnew 2011, s. 326-327].

Co zatem mówili badani o Krakowie jako o miejscu? Należy przede wszystkim zaznaczyć, że stanowili oni wśród rozmówców mniejszość. Kraków stanowił przestrzeń nacechowaną bądź taką, w której lokowano pewne obiekty i aktywności. Bywało także wiązane z ,ja”, z osobistym doświadczeniem jednostki lub też jej działaniami w miejscu.

Dobrą ilustracją tego pierwszego aspektu jest następująca wypowiedź: „Yyy... Tak więc jest bardzo ciekawym miejscem. Eee... Jest bardzo magicznym miejscem. Jest też jakby takim ośrodkiem kulturalnym. Znajduje się tutaj wiele jakichś ciekawych, interesujących, no nie wiem, na przykład muzeów czy wiele jest jakichś organizowanych yyy... festiwali czy coś w tym stylu, na przykład dla studentów. Yyy... nie wiem" (10/K_21_P). Inna uczestniczka badań stwierdziła: „Jest bardzo pięknym miejscem w Polsce” (15/K_21_P), a w innej części wywiadu dodała: „Jest też miejscem dla studentów, gdzie można zawsze dobrze się bawić i też spędzić czas w ciekawy sposób" (15/K_21_P). Inni zaś stwierdzili: „Hmmm... miejscem artystycznym” (32/K_35_P); „Piękne miejsce, miasto, zwłaszcza nocą" (43/M_19_P).

Gdy rozmówcy wspominali o Krakowie/miejscu i zaznaczali osobiste z nim powiązanie, były to wyraźne nawiązania afektywne. Badani mówili o Krakowie jako „bliskim sercu”: „Yyy... jest to miejsce, w którym nie wiem, chciałabym zostać na przyszłość. Yyy... które na pewno jakoś wiąże się z moją przyszłością. W którym chciałabym zostać i jest jakieś bliskie mojemu sercu" (11/K_21_P); „Kraków jest dla mnie bliskim miejscem, w którym jestem od dawna i czasami mam go dość i chciałabym się z niego wyprowadzić, ale jednak jest to miasto najbliższe memu sercu” (21/K_22_U); „Moim pewnym bliskim miejscem” (28/K_26_U). Kraków był też nazywany domem: „No mieszkam tutaj już wiele lat, więc myślę, że moim domem" (22/K_22_U).

Jeśli chodzi o aktywności, które badani lokowali w Krakowie/miejscu, przede wszystkim można było usłyszeć o Krakowie jako „miejscu życia”, w którym podmiot się urodził, mieszka, uczy się i pracuje: „Kraków jest miejscem, gdzie mieszkam... gdzie pracuję” (53/M_24_P); „Jest miejscem, gdzie się bawię, uczę. Miejscem, w którym po prostu żyję” (65/M_32_P); „Miejscem, gdzie załatwiam wszystkie sprawy urzędowe. Tu mam przyjaciół, uniwersytet; uczę się. Większa cześć mojego życia skupia się wokół tego terenu" (28/K_26_U). 
Na koniec należy zaznaczyć, że rozmówcy nie zawsze konsekwentnie używali na określenie Krakowa ekwiwalentu miasta i miejsca, chociaż byli również tacy. Niekiedy w jednym zdaniu występowały obydwa te określenia, co pozwala przypuszczać, że używali ich zamiennie.

W obszarze omawianej kategorii ekwiwalentów dominowało odnoszenie Krakowa do kategorii miasta. Uwagę zwraca fakt, że wśród osób urodzonych w Krakowie więcej było tych, którzy zarówno miasto, jak i miejsce naznaczali rysem osobistym, odnosząc Kraków do swojej biografii i doświadczeń. Większość opisów prezentowanych przez przybyszów robiło wrażenie takich, które tworzone są z dystansu, brakowało bowiem komunikatów pozwalających stwierdzić, jakie związki z Krakowem/miastem czy Krakowem/miejscem odczuwają.

\subsection{Określenia}

W tej części opracowania zdecydowano się wykorzystać rozwinięcie analiz zaproponowane przez B. Fatygę, które dotyczyło dokonywania kontekstowo uwarunkowanego pomiaru temperatur emocjonalnych wyrażeń składających się na sieć określeń (por. [Fatyga 2015, s. 160]). Chcąc zachować czytelność prowadzonych analiz, wybrano uproszczoną wersję dzielącą określenia na pozytywne, negatywne, ambiwalentne i neutralne. Na tak skonstruowaną sieć porządkującą nałożono kolejną oś podziału dzielącą określenia nawiązujące do osobistego i nieosobistego stosunku do Krakowa.

\section{Kraków jest mój - określenia osobiste}

Wśród określeń osobistych wiele odnosiło się do opisu Krakowa jako własnego miejsca, np.: ,jest moim miastem” (59/M_27_U) lub „moim miejscem pracy” (25/K_26_P). Były to określenia osobiste, wskazujące na rolę podmiotu poznającego jako ośrodka formułującego opinie, ale ich temperatura była neutralna. Wskazywały na to same określenia, jak i kontekst przytoczonych wypowiedzi. Powyższe cytaty pozwalają także zobrazować różnicę w postrzeganiu miasta przez przybyszów i osoby urodzone w Krakowie. W przypadku tych pierwszych Kraków jako miasto traktowany jest jako własny, a więc oswojony, w przypadku drugich oswojony jest tylko w jednym, konkretnym wymiarze (np. w wymiarze zawodowym).

Określenia osobiste o wyraźnie pozytywnym nacechowaniu dotyczyły w dużej mierze atmosfery miasta, której doświadczają mieszkańcy. Określenia te można połączyć także częściowo z koncepcją genius loci Krakowa, którą opisywał J. Mikułowski-Pomorski [1996]. Warto zauważyć, że w przypadku określeń osobistych pozytywnych nie występuje wyraźny podział między mieszkańcami od urodzenia a tymi, którzy do Krakowa się przeprowadzili. W narracjach zarówno 
jednych, jak i drugich Kraków jawi się jako miejsce magiczne, wyjątkowe i tajemnicze, co obrazują poniższe wypowiedzi: „(...) czy też są na przykład okolice rynku, bliskie ulice, gdzie jest pełno jakichś kamienic. Bardzo jest magiczny, taki hmm... ma taki swój jakby... yyy... nie wiem, taki nastój panuje" (10/K_21_P); „Jest wyjątkowy, jest szybki, jest, czasami jest jak Londyn (...), gdzie ludzie mijają się i czasami nie zauważają, ale mimo wszystko Kraków jest wyjątkowy" (21/K_22_U); „Może dla turystów jest tajemniczy” (27/K_26_U); „Tajemniczy” (48/M_22_P).

Wśród określeń osobistych zabarwionych negatywnie najwięcej jest tych, które odnoszą się do jakości życia w mieście, a więc przede wszystkim do zanieczyszczenia powietrza: „Jest śmierdzący i zasmogowany” (28/K_26_U); ,Jest miastem troszeczkę zanieczyszczonym, chociażby z uwagi na ten smog" (44/M_21_P), oraz problemów w zakresie poruszania się w przestrzeni. Respondenci twierdzili, że Kraków jest „zatłoczony” (23/K_22_U) i „,zakorkowany” (60/M_27_U); „Kraków jest miastem ponoć dobrze rozwiniętym, jeśli chodzi o komunikację, jeśli chodzi o drogownictwo, natomiast cały czas są problemy z korkami” (45/M_21_P). Wśród osobistych określeń zabarwionych negatywnie warto także zauważyć te, które wskazywały na bezpośrednią więź z Krakowem i emocje, jakie w oceniających wzbudzał: ,jest czasami denerwujący i irytujący” (7/K_21_U) lub „troszkę przytłaczający" (44/M_21_P).

\section{Kraków jest, jaki jest - określenia nieosobiste}

W kategorii określeń nieosobistych przeważały określenia pozytywne, opisujące głównie walory estetyczne. Zdaniem respondentów Kraków jest więc piękny, ładny i malowniczy, co obrazują poniższe wypowiedzi: „Jest piękny pod względem może też architektonicznym. Mnie się podobają osobiście te rynkowe uliczki” (13/K_21_P); ,Jest pięknym miastem, jednym z najpiękniejszych w Europie” (50/M_22_U); „No tak jak powiedziałem, malownicze miasto” (67/M_39_P); „Kraków jest ładny” (49/M_22_U).

W kategorii pozytywnych określeń nieosobistych znalazły się także te opisujące cechy miasta istotne zwłaszcza z perspektywy osób przyjezdnych, szukających swojego miejsca w przestrzeni miasta. W tej grupie znalazły się określenia, takie jak: „otwarty”, ,pełen możliwości”, ,przyjazny”, ,atrakcyjny”. Najlepiej obrazują to poniższe wypowiedzi: „A więc jest miastem bardzo przyjaznym, otwartym na... yyy... dla ludzi tutaj przybywających, pełnym jakichś perspektyw, możliwości” (6/K_21_P); ,Jest duży, jest przyjazny dla studentów” (66/M_34_P); „Na pewno atrakcyjny dla turystów” (29/K_26_U).

W kategorii określeń neutralnych znalazły się te odwołujące się do dziedzictwa kulturowego Krakowa. Kraków w narracjach badanych był zabytkowy i historyczny, co obrazują poniższe wypowiedzi: „No Kraków jest, jaki jest. Wydaje 
mi się, że jest, no, historycznym miastem, zabytkowym i że w porządku się tutaj żyje. No i tyle” (55/M_25_P); „Kraków jest zabytkowy na pewno” (20/K_22_U). W tej grupie znalazły się także przymiotniki, takie jak: „duży”, ,ułożony”, ,,nowoczesny” i „międzynarodowy”.

W kategorii określeń negatywnych znalazły się takie jak „brudny” i „zanieczyszczony". W tym wypadku różnica między odniesieniami osobistymi a nieosobistymi wynikała głównie z kontekstu. W przypadku określeń osobistych respondenci wskazywali, jak dane przymioty Krakowa powiązane są negatywnie z jakością ich życia w mieście, a w przypadku określeń nieosobistych badani referowali jedynie fragmenty aktualnego dyskursu medialnego dotyczącego Krakowa, w którym w okresie realizacji badań przeważały komunikaty dotyczące smogu i zanieczyszczenia powietrza.

\subsection{Asocjacje}

Skojarzenia z Krakowem, które mieli uczestnicy badań, układają się wokół trzech głównych osi. Zostały one określone jako: przeszłość, ekologia/infrastruktura i biografia.

Najczęściej łączono Kraków z przeszłością i to w różnych kontekstach. Przede wszystkim były to obiekty zabytkowe. Wśród najczęściej wymienianych znalazł się Wawel, następnie Sukiennice, Rynek Główny i kościół Mariacki, np.: „No Kraków kojarzy mi się z Wawelem" (11/K_21_P). Niejednokrotnie wymieniano jednym tchem kilka z nich: „No oczywiście z historią, z Wawelem, z zamkiem właśnie na Wawelu, z Sukiennicami, z przepięknym rynkiem" (20/K_22_U); „Z czym mi się kojarzy? No to z jakimiś takimi... nie wiem, na przykład... yyy... bardzo z jakimiś zabytkami albo z jakimiś obwarzankami, takie rzeczy na przykład. Nie wiem... na przykład z rynkiem... no wiadomo, kościół Mariacki - i te sprawy" (13/K_21_P).

Wspomniane obiekty nie były jednak elementami z przeszłości, które najczęściej wspominano. Jak się okazało, swoistą ikoną Krakowa jest smok wawelski: „Mi się kojarzy ze smokiem wawelskim” (15/K_21_P); „No mi zawsze się kojarzy ze smokiem wawelskim" (35/K_45_U). Smok pojawiał się też w pewnych sieciach skojarzeniowych, np. z Wawelem: „Mi się kojarzy Kraków z Wawelem i ze smokiem wawelskim” (10/K_21_P); „Kraków kojarzy się z lajkonikiem, kojarzy się ze smokiem wawelskim, kojarzy się z Wawelem” (K_22_U); „Kraków kojarzy się z kościołem, ze smokiem wawelskim" (5/K_20_U). Oprócz smoka przywoływano także lajkonika. Można więc powiedzieć, że pewne namacalne znamiona przeszłości współistnieją w świadomości badanych z elementami mitycznymi, z legendą, tworząc typowe zbitki skojarzeń. Ilustruje to poniższy cytat: „Kraków kojarzy się z lajkonikiem, kojarzy się ze smokiem wawelskim, 
kojarzy się z Wawelem" (20/K_22_U). W wypowiedziach badanych pojawiało się też nawiązanie do faktu, że Kraków był kiedyś stolicą Polski, siedzibą królów. Kraków kojarzony z przeszłością waloryzowany był wyraźnie pozytywnie.

Z Krakowem kojarzono też rzekę Wisłę. Część rozmówców przywoływała ten element przyrody jako charakterystyczny dla Krakowa. Jak powiedział jeden z rozmówców: „Z czym kojarzy się Kraków? Z Wisłą, proszę Pani, z Wisłą” (47/M_22_P).

Drugim kluczowym obszarem, w którym lokują się skojarzenia z Krakowem, jest ekologia. Były to przede wszystkim negatywne skojarzenia. W bardzo wielu wypowiedziach nawiązywano do kwestii krakowskiego smogu. Mówiono, że: „Kraków kojarzy się z brakiem powietrza i dużym smogiem” (50/M_22_U); „Kraków kojarzy mi się ze smogiem, z zanieczyszczonym powietrzem” (12/K_21_P). Być może tak liczne skojarzenia związane z tą kwestią wynikały z okresu, w którym prowadzono badania - był to grudzień 2016 r., kiedy nie tylko stan powietrza w mieście był bardzo zły, ale też wiele mówiło się o tym w mediach. Nie zmienia to jednak faktu, że równie często co o krakowskich zabytkach czy smoku wspominano o smogu. Niekiedy wymieniano je łącznie, np. w wypowiedziach: „No dalej, że jest zanieczyszczony, zabytkowy, ze smogiem” (55/M_25_P); „Kraków kojarzy mi się ze smogiem, z zanieczyszczonym powietrzem, ale też z różnymi zabytkami, z Wawelem, Wisłą, z fajnymi miejscami” (9/K_21_P).

W pewnym sensie wspomniane wątki podsumowuje poniższy cytat: „Kraków kojarzy mi się z Wawelem i smokiem wawelskim, i z Wisłą" (6/K_21_P).

Negatywne nawiązania czyniono również wobec infrastrukturalnego aspektu miasta. Respondenci wspominali przede wszystkim o korkach na ulicach, np.: „Kojarzy mi się z dużą ilością korków, które są w naszym mieście, natłokiem ludzi w komunikacji miejskiej i oczywiście ze smogiem, który zanieczyszcza Kraków” (59/M_27_U). Kilka osób wspominało o dużym tłoku w mieście, co dotyczyło nie tylko samochodów, ale ludzi: „Kraków kojarzy mi się z tłumem ludzi i ciągłymi korkami na drogach” (66/M_34_P); ,Zawalonym przez społeczność miastem, które nie robi nic z problemem smogu" (46/M_21_P).

Niewielka część rozmówców, myśląc o Krakowie, przywoływała te skojarzenia, zwłaszcza pozytywne, które odnosiły się do ich biografii czy własnych doświadczeń z miejscem lub ludźmi. Najczęściej czyniły tak osoby urodzone w tym mieście. Przykładowo mówili o wczesnych przeżyciach. Kraków kojarzył im się: „Z moim dzieciństwem” (27/K_26_U); ,Z moją młodością i najlepszym okresem w moim życiu” (19/K_22_U). Wspominano też o bliskich osobach: „Chyba będę go kojarzyć z rodziną” (20/K_20_U); ,Z moim domem, rodziną i przyjaciółmi, którzy mieszkają tutaj razem ze mną od małego" (61/M_28_U). 


\subsection{Opozycje}

Tworząc sieć opozycji wobec Krakowa, wypowiedzi badanych najłatwiej przedstawić w podziale na trzy grupy, dotyczące nie tylko tego, czym Kraków nie jest, ale także tego, czego Kraków nie ma i czego mu brakuje.

Najczęśsiej pojawiającą się spontanicznie odpowiedzią na pytanie o to, czym Kraków nie jest, było stwierdzenie: „Nie jest już stolicą” (27/K_26_U). Wypowiedzi respondentów można podzielić na te, które przeciwstawiają Kraków „stolicy”, i takie, które przeciwstawiają Kraków „Warszawie” jako innemu miastu: „Kraków nie jest na pewno Warszawą albo jakimś innym miastem” (14/K_21_P). Równie często jako opozycja do Krakowa pojawiała się wieś.

W określaniu tego, czym Kraków nie jest, respondenci posługiwali się także opisem tego, czego w mieście brakuje, a jest obecne w innych miastach. Na pierwszym miejscu znalazło się metro, w dalszej kolejności pojawiły się odniesienia do geograficznych własności miasta, a więc brak dostępu do morza i gór. W tej grupie znalazły się także elementy, które odnosiły się do organizacji życia w mieście. Respondenci wskazywali na braki w sferze władzy: „Kraków nie posiada też, Kraków nie ma odpowiedniej osoby, która zarządzałaby tym miastem” (2/K_18_P), organizacji przestrzeni: „No może tych terenów zielonych, większej ilości ekologicznych autobusów, drzew” (66/M_34_P), „Brakuje tu miejsc parkingowych” (67/M_39_P), czy komunikacji: „Nie ma wystarczająco autobusów i tramwajów" (9/K_21_P).

Dużo uwagi badani poświęcili także opisowi braku świeżego powietrza: "Nie jest na pewno miastem, który jakby świeci przykładem, jeżeli chodzi o czyste powietrze” (11/K_21_P), „Krakowowi brakuje czystego powietrza” (17/K_22_P); „Nie jest miejscem, gdzie można pooddychać świeżym powietrzem” (50/M_22_U). W wypowiedziach znalazły się też osobiste odniesienia do braków Krakowa: „Nie jest moim rodzinnym domem” (25/K_26_P).

\subsection{Opis działań podmiotu}

Na pytanie, co robi Kraków, jedna z rozmówczyń odpowiedziała: „Oj, Kraków robi wiele rzeczy" (9/K_21_P). W przypadku działań Krakowa, tak jak je postrzegali rozmówcy, odpowiedzi były rozproszone. Da się je jednak rozpisać ze względu na ich waloryzację na osi pozytywne-negatywne.

Wśród działań Krakowa, które kategoryzowano jako pozytywne, można wskazać to, że Kraków żyje. Tak o tym mówili badani: „No Kraków żyje...” (13/K_21_P); „Żyje swoim życiem” (17/K_22_P); „Tętni życiem. Żyje dzięki studentom” (22/K_22_U). Kraków również się bawi/imprezuje: „Bawi się, pracuje, pije, no i co ma robić miasto, no miasto żyje" (55/M_25_P). 
Rozmówcy stosunkowo często wspominali o tym, że Kraków się rozwija: „No Kraków się rozwija” (6/K_21_P); „Szybko rozwija się” (49/M_22_U). „Czasem dookreślano, w jakim znaczeniu: „Rozwija się. Rozwija się, w sensie poszerza się jako miasto, że już nie jest tylko centrum, tylko całość, obrzeża” (19/K_22_U); „Na pewno Kraków się rozwija, ciągle widzimy jakieś nowo powstające budynki” (66/M_34_P).

Ponadto Kraków uczy i kształci, przede wszystkim studentów: „Kształci młodych ludzi” (23/K_23_P); „Kształci ludzi jako miasto studenckie” (M_28_P).

Zdaniem uczestników badania Kraków również przyciąga do siebie, szczególnie turystów: „Przynagla do siebie wielu turystów” (55/M_23_U); „Na pewno przyciąga wielu turystów właśnie tymi zabytkami, o których mówiłam" (18/K_22_P).

Kraków nie tylko przyciąga, ale też daje. Wspominano o tym, że daje możliwości. Badani nie precyzowali, jakie to możliwości, lub też wskazywali je konkretnie. W tym drugim przypadku miasto/miejsce daje przede wszystkim pracę: „Na pewno daje pracę, nie tylko mieszkańcom, ale także przyjezdnym osobom” (29/K_26_U); „Daje dużo miejsca zatrudnienia (50/M_22_U). Dostarcza też możliwości rozwoju: „Daje możliwości rozwoju zawodowego” (59/M_27_U); „Daje możliwości do rozwoju, do nauki, do poznania głębszego siebie” (15/K_21_P). Zachęca także, jak można było usłyszeć: „Zachęca turystów do przyjazdu i do zwiedzenia, zachęca ludzi do pracy” (43/M_19_P); „Na pewno zachęca ludzi do zwiedzania, yyy... nie tylko z Polski, jak i ze świata" (29/K_26_U).

Dobrym podsumowaniem wskazanych wyżej pozytywnych działań Karkowa jest następująca wypowiedź: „Co robi Kraków? Hmm... Może odpowiem na to w ten sposób, że tak jakby Kraków... hmm... nie wiem... jakby... stwarza taką niesamowitą atmosferę, że... hmm... jakby zachęca... nie wiem... na przykład wiele osób, wiele moich znajomych, na przykład, tak samo czuje się tutaj świetnie, yyy... jest to takie miejsce, gdzie naprawdę można poznać, spotkać jakichś ciekawych ludzi... yyy... także, nie wiem... stwarza tak jakby taką jakąś atmosferę, nie wiem... taką magiczną, że czujemy się tutaj dobrze i... nie wiem... że nie chcemy stąd wracać" (13/K_21_P).

Istnieje także negatywna strona działań Krakowa, na którą zwracali uwagę uczestnicy badań. Odnosiła się ona do zanieczyszczenia środowiska - Kraków truje. Można było spotkać takie opinie: „Wydaje mi się, że truje mieszkańców” (4/K_20_P). Ukazują one wyraźnie przypisane miastu/miejscu sprawstwo w tym zakresie. Podkreślano też, że: „Dusi się smogiem” (49/M_22_U). 


\subsection{Opis działań wobec podmiotu}

Na pytanie o to, jakie działania można podjąć wobec Krakowa, badani odpowiadali najczęściej, wskazując aktywności w różnych obszarach. Były one głównie związane z przestrzenią i organizacją życia w mieście. Działania te można podzielić na cztery grupy: o charakterze bardzo ogólnym - nieprecyzujące kierunku zmian, mające na celu rozwój/rozbudowę, ograniczające negatywne zjawiska oraz prowadzące do wykorzystania istniejących zasobów, dokończenia rozpoczętych przedsięwzięć. Ogólne sugestie zmian można opisać za pomocą czasowników „zmienić”, „ulepszyć”, co obrazuje najlepiej poniższy cytat: „No na pewno można jakoś w pewien sposób go ulepszyć. Na przykład, teraz nawet nie wiem, jak to powiedzieć... Nie wiem sama, o czym mogłabym tutaj wspomnieć, ale na pewno są jakieś, pewne, yyy... rzeczy, które można by było zmienić, tak? Wprowadzić. Nie wiem... Właśnie jakieś zmiany, ale no nie wiem, jak to teraz sprecyzować" (10/K_21_P).

W grupie działań mających na celu rozwój/rozbudowę znalazły się: 1) budowanie nowych obiektów: „Zbudować nowe budynki, bardziej europejskie takie, powiedzmy” (55/M_25_P), „Budować place zabaw... yy... na pewno miejsca, gdzie można odpocząć, usiąść, parki... yyy... miejsca, gdzie można spotykać się z ludźmi” (29/K_26_U); 2) dotyczące bliżej niesprecyzowanego rozwoju: „Można go jeszcze bardziej rozwijać, żeby był jeszcze bardziej przyjazny dla młodych ludzi i nie tylko dla młodych ludzi" (21/K_22_U); 3) dotyczące rozwoju komunikacji: „Zmienić wszystkie tramwaje na nowsze, żeby komfort jazdy się poprawił nie tylko dla młodych ludzi, ale przede wszystkim osób starszych i niepełnosprawnych” (59/M_27_U); 4) dotyczące rozwoju obszarów zielonych: „Zwiększyć powierzchnię terenów zielonych" (53/M_24_P).

Wśród działań mających ograniczyć negatywne procesy najwięcej dotyczyło komunikacji: „Zlikwidować korki” (32/K_35_P), „Można zremontować kilka, kilka skrzyżowań, zmodernizować” (45/M_21_P), oraz poprawienia jakości środowiska naturalnego: „No oczyścić powietrze. Nie wiem, Wisłę oczyścić, zrobić coś, żeby nie było tutaj tego smogu" (7/K_21_P).

Badani wskazywali także na wykorzystanie istniejących zasobów i/lub kontynuowanie działań już podjętych: „Przede wszystkim trzeba skończyć obwodnicę, żeby była pełna, gdyż to wstyd, żeby takie miasto nie miało pełnej obwodnicy" (50/M_22_U); „Wydaje mi się głównie, że działania restauracyjne, to znaczy większość tutaj jednak zabytków jest dosyć, dosyć, dosyć w ciężkim stanie i bardzo dobrze by było, gdyby jednak zostały odnowione" (63/M_32_P).

Postulaty te można traktować także jako pewne ścieżki prowadzące Kraków w stronę miasta idealnego. Działania wymienione przez badanych można uporządkować jako takie, które miałyby sprawić, że Kraków stałby się retropolis (nacisk 
na dziedzictwo kulturowe i zabytki), ekopolis (nacisk na działania proekologiczne) czy neopolis (nacisk na działania unowocześniające) (Paszkowski, 2011).

\section{Zakończenie}

Podsumowując rozważania, należy zwrócić uwagę na kilka kwestii. Przede wszystkim obraz Krakowa wyłaniający się z przeprowadzonych badań każe myśleć o nim jako mieście/miejscu. Kraków ujmowany był przez badanych przede wszystkim jako miasto/miejsce nasycone symbolami (Wawel), mitami (smok), dziedzictwem kulturowym, czyli przeszłością. Był raczej opisywany jako struktura przestrzenna, w której coś ulokowano (np. zabytki). Wizerunek wyłaniający się z narracji można więc bardziej porównać do pocztówki (gdzie ważne są miejsca, obiekty) niż do zdjęć zamieszczanych na popularnym obecnie Instagramie (gdzie często jest też autor zdjęcia). Badani patrzyli na Kraków z pewnego dystansu. Nie oznacza to, że nie komunikowali osobistego stosunku do miasta/miejsca, gdyż część z nich wiązała z nim swe doświadczenia i biografie. Nie była to jednak perspektywa dominująca, co może wynikać także z charakteru próby, która obejmowała osoby stosunkowo niedawno przybyłe do Krakowa. Można więc przypuszczać, że nie wydeptały one jeszcze w tym mieście swoich ścieżek.

Co ciekawe, narracje nie ukazały właściwie różnorodności społecznej miasta/miejsca w wymiarze demograficznym czy strukturalnym. Z opisów prezentowanych przez rozmówców wyłania się fasadowy wizerunek Krakowa, za którym nie kryją się ludzie, chyba że są to turyści i studenci. Kraków nie jawi się więc jako złożona społeczno-przestrzenna całość.

W analizowanych wypowiedziach Kraków był estetyzowany i oceniany pozytywnie. Miasto/miejsce opisywano nie tylko jako piękne, ale też jako żywe, rozwijające się, przyciągające, dające, a jedyną rysą jest aspekt ekologiczny. Podstawową kategorią rozumienia był smog, brud. Używając metafory, można powiedzieć, że Kraków miasto/miejsce lokuje się między smokiem a smogiem.

Jak pisała E. Rewers: „W jednym mieście może ukrywać się wiele miast: miasta mentalne mieszkańców i miasta fizyczne budowniczych, nieruchome miasta obiektów i miasta ciał w ruchu, miasta jednostkowych taktyk i miasta instytucjonalnych strategii, miasta nostalgicznych pamięci i miasta futurystycznych akcji, miasta widzialne oraz «niewidzialne», realne i wirtualne, a także dziesiątki innych" [2009, s. 15]. Zaprezentowane wyniki analiz pokazują zapewne jedno z tych miast - to widziane oczami badanych. 


\section{Literatura}

Agnew J.A. [2011], Space and Place [w:] The Sage Handbook of Geographical Knowledge, eds J.A. Agnew, D.N. Livingstone, Sage, Los Angeles.

Charmaz K. [2013], Teoria ugruntowana: praktyczny przewodnik po analizie jakościowej, Wydawnictwo Naukowe PWN, Warszawa.

Dudkiewicz M. [2006], Zastosowanie analizy pola semantycznego i analizy gloss dla zaprezentowania sposobu postrzegania świata społecznego, „Przegląd Socjologii Jakościowej", nr 1.

Glaser B., Strauss A. [1967], The Discovery of Grounded Theory, Aldine, Chicago.

Kłosiński M. [1994], Semantyczna analiza pojęć „,bezrobocie” $i$, bezrobotny” („bezrobotni”) w wypowiedziach prasowych, „Kultura i Społeczeństwo”, nr 3.

Konecki K. [2000], Studia z metodologii badań jakościowych: teoria ugruntowana, Wydawnictwo Naukowe PWN, Warszawa.

Majer A. [2015], Miasta teoretyczne [w:] Społeczne i ekonomiczne aspekty urbanizacji i metropolizacji, red. M. Malikowski, M. Palak, J. Halik, Uniwersytet Rzeszowski, Rzeszów.

Mikułowski-Pomorski J. [1996], Genius loci w przestrzeni miejskiej [w:] Kraków-Małopolska w Europie środka. Studia ku czci profesora Jana M. Małeckiego w siedemdziesiata rocznicę urodzin, red. J. Purchla, J. Szpak, K. Broński, Universitas, Kraków.

Paszkowski Z. [2011], Miasto idealne w perspektywie europejskiej i jego zwiqzki z urbanistykq współczesnq, Universitas, Kraków.

Praktyki badawcze [2015], red. B. Fatyga, Instytut Stosowanych Nauk Społecznych UW, Warszawa.

Rewers E. [2009], Od miejskiego genius loci do miejskich oligopticonów [w:] Materiały konferencji zorganizowanej przez Muzeum Pałac w Wilanowie, Instytut Historii Sztuki Uniwersytetu Kardynała Stefana Wyszyńskiego, Warszawa.

Robin R. [1980], Badanie pól semantycznych: doświadczenia Ośrodka Leksykologii Politycznej w Saint-Cloud [w:] Język i społeczeństwo, red. M. Głowiński, Czytelnik, Warszawa.

Straś-Romanowska M. [2010], Badania ilościowe vs jakościowe - pytanie o tożsamość psychologii, ,Roczniki Psychologiczne”, t. XIII, nr 1.

\section{What Is Cracow? A Semantic Field Analysis}

(Abstract)

The article presents ways the inhabitants of Cracow define the city they live in. It is based on the results of qualitative research, elaborated using semantic field analysis of the term "Cracow", which enabled us to show how people define Cracow, how they describe it, what they associate it with, what it is thought to stand against, what Cracow does and what can be done to Cracow.

Keywords: semantic analysis, city, space, urban sociology, Cracow, qualitative sociology. 